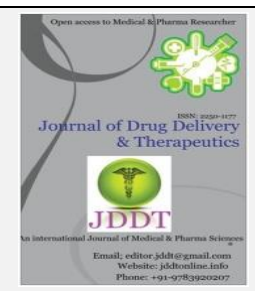

Research Article

Open $\odot$ Access

\title{
Development and Validation of UV Spectroscopic Method for Estimation of Baricitinib.
}

\author{
Santosh V. Gandhi*, Barkha G. Kapoor \\ AISSMS College of Pharmacy, Savitribai Phule Pune University, Pune, India-411001
}

\begin{abstract}
A simple, sensitive and reproducible spectrophotometric method for the analysis of Baricitinib in pure form and in its dosage form has been developed. Baricitinib is a synthetic antineoplastic and immunomodulating drug. Baricitinib is a selective and reversible Janus kinase 1 (JAK1) and 2 (JAK2) inhibitor. Janus kinases belong to the tyrosine protein kinase family and play an important role in the proinflammatory pathway signalling that is frequently over-activated in autoimmune disorders such as rheumatoid arthritis. Developed method obeyed beer's law in a concentration range of $10-60 \mu \mathrm{g} / \mathrm{ml}$ with a correlation coefficient $\left(\mathrm{R}^{2}\right)$ of 0.993 . Quantification was carried out at $250 \mathrm{~nm}$. Percentage assay of Baricitinib was found to be close to $100 \%$. The results of analysis have been validated statistically and recovery studies confirmed the accuracy of the proposed method.
\end{abstract}

Keywords: Spectrophotometric method, Baricitinib, Antineoplastic, immunomodulating, Beer's law.

Article Info: Received 13 June 2019; $\quad$ Review Completed 28 July 2019; Accepted 07 Aug 2019; Available online 15 August 2019

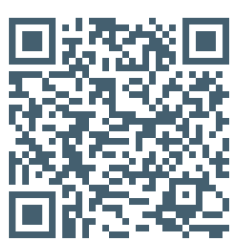

Cite this article as:

Gandhi SV, Kapoor BG, Development and Validation of UV Spectroscopic Method for Estimation of Baricitinib., Journal of Drug Delivery and Therapeutics. 2019; 9(4-s):488-491 http://dx.doi.org/10.22270/jddt.v9i4-s.3230

*Address for Correspondence:

Dr. Santosh V. Gandhi, Professor, AISSMS College of Pharmacy, Savitribai Phule Pune University, Pune, India-411001

\section{INTRODUCTION:}

Baricitinib is chemically, 2-[1-(ethanesulfonyl)-3- $(4-\{7 \mathrm{H}-$ pyrrolo[2,3-d]pyrimidin-4-yl\}-1H-pyrazol-1-yl)azetidin-3yl]acetonitrile. It is used for the treatment of moderate to severe active rheumatoid arthritis in adult patients who have responded inadequately to, or who are intolerant to one or more disease-modifying anti-rheumatic drugs as monotherapy or in combination with methotrexate. Upon administration, baricitinib binds to JAK1/2, which inhibits JAK1/2 activation and leads to the inhibition of the JAKsignal transducers and activators of transcription (STAT) signaling pathway. This decreases the production of inflammatory cytokines and may prevent an inflammatory response. In addition, baricitinib may induce apoptosis and reduce proliferation of JAK1/2-expressing tumor cells. JAK kinases are intracellular enzymes involved in cytokine signaling, inflammation, immune function and hematopoiesis; they are also upregulated and mutated in various tumor cell types. In February 2017, Baricitinib was approved for use in the EU as a second-line oral therapy for moderate to severe active rheumatoid arthritis in adults, either alone or in combination with methotrexate. It is marketed under the trade name Olumiant. [1-3]. The structure of Baricitinib is given in Fig 1.<smiles>CCS(=O)(=O)N1CC(CC#N)(n2cc(-c3ncnc4[nH]ccc34)cn2)C1</smiles>

Fig 1: Structure of Baricitinib

As per the literature survey the data shows that simultaneous quantification of Baricitinib and Methotrexate in rat plasma by LC-MS/MS is reported [4]. No spectroscopic method has been reported for estimation of baricitinib in bulk or dosage form. The present manuscript describes simple and sensitive spectroscopic procedure for the determination of baricitinib in accordance with International Conference on Harmonisation Guidelines. [5] 


\section{MATERIALS AND METHODS:}

\section{CHEMICALS AND REAGENTS:}

Baricitinib bulk powder was kindly gifted by Bulat Pharmaceutical Pvt. Ltd. India. Methanol AR grade was purchased from S.D. Fine Chemical Laboratories, Mumbai and DMSO AR grade was purchased from Loba Chemie Pvt. Ltd., Mumbai.

\section{Preparation of standard stock solution:}

Standard stock solution of drug was prepared by dissolving $10 \mathrm{mg}$ of drug in $1 \mathrm{ml}$ of DMSO (as the drug is sparingly soluble in methanol) and future volume was made up with methanol till $10 \mathrm{ml}$ to get concentration of $1000 \mu \mathrm{g} / \mathrm{ml}$. From this solution $1 \mathrm{ml}$ was taken in $10 \mathrm{ml}$ volumetric flask and volume was made up with methanol to get concentration of solution $100 \mu \mathrm{g} / \mathrm{ml}$. Further $1 \mathrm{ml}$ of this solution was diluted to $10 \mathrm{ml}$ with methanol to get concentration of solution 10 $\mu \mathrm{g} / \mathrm{ml}$.

\section{Selection of detection wavelength:}

From the standard stock solution (1000 $\mu \mathrm{g} / \mathrm{ml})$ further dilutions were made using methanol and scanned over the range of 220-375 $\mathrm{nm}$ against methanol as blank and the spectra was obtained. It was observed that the drug showed linear, stable and considerable absorbance at $250 \mathrm{~nm}$ Representative UV spectrum of Baricitinib is shown in Fig. 2

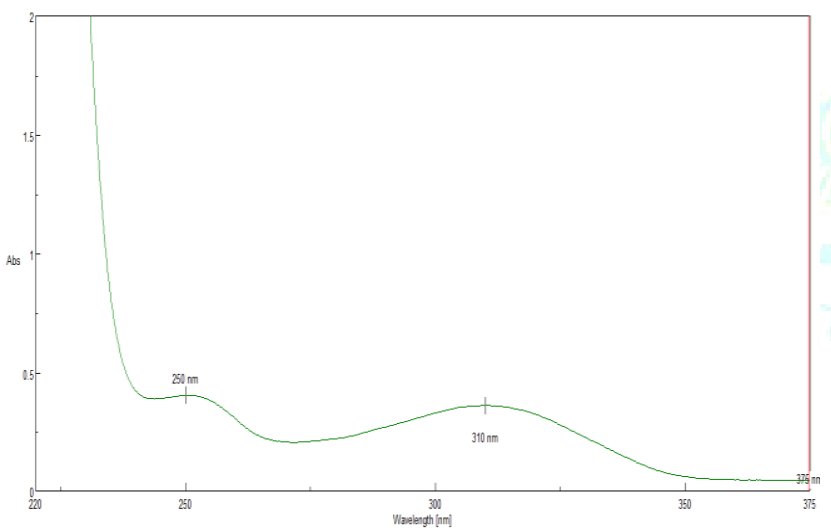

Figure 2: UV Spectrum of Baricitinib $(10 \mu \mathrm{g} / \mathrm{ml})$

In house preparation of formulation (For Assay)

Formulation for Baricitinib was prepared by geometric mixing of commonly used excipients for tablet formulation with drug. All ingredients were accurately weighed and geometrically mixed. List of the ingredients is shown in Table 1.
Table 1: List of ingredients for in house preparation of Formulation

\begin{tabular}{|c|c|}
\hline Name of Ingredient & Quantity Taken (for 100mg) \\
\hline Baricitinib & $2 \mathrm{mg}$ \\
\hline Microcrystalline & $28 \mathrm{mg}$ \\
\hline Mannitol & $70 \mathrm{mg}$ \\
\hline
\end{tabular}

\section{VALIDATION OF THE PROPOSED METHOD:}

The method was validated with respect to linearity, accuracy, precision, limit of detection and limit of quantification according to the ICH guidelines [5]

\section{Linearity:}

Standard stock solution of drug was prepared by dissolving $10 \mathrm{mg}$ of drug in $1 \mathrm{ml}$ of DMSO (as the drug is sparingly soluble in methanol) and future volume was made up with methanol till $10 \mathrm{ml}$ to get concentration of $1000 \mu \mathrm{g} / \mathrm{ml}$. Further $1 \mathrm{ml}$ was taken and diluted to $10 \mathrm{ml}$ with methanol in volumetric flask to get $100 \mu \mathrm{g} / \mathrm{ml}$. This solution was further diluted with methanol to get range of solution containing different concentrations 10-60 $\mu \mathrm{g} / \mathrm{ml}$. Absorbance was noted at $\lambda \max 250 \mathrm{~nm}$. The equation of calibration curve by UV- Spectroscopy was found to be $\mathrm{y}=0.031 \mathrm{x}+0.080$ with $\mathrm{R}^{2}=0.993$. The absorbance of drug was plotted against the corresponding concentrations to obtain the calibration curve as shown in Fig. 3

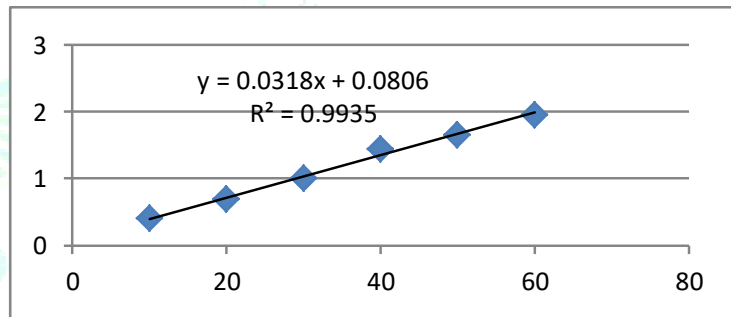

Fig 3: Linearity curve of Baricitinib by UV-Spectroscopy (10-60 $\mathrm{gg} / \mathrm{ml})$.

\section{PRECISION:}

The intraday and interday precision of the proposed method were performed by analyzing the corresponding responses 3 times on the same day and on 3 different days for 3 different concentrations of standard solutions of Baricitinib $(20,30$ and $50 \mu \mathrm{g} / \mathrm{ml}$ ) without changing the parameters for the method. The results were reported in terms of relative standard deviation (\% RSD). The results obtained for intraday and inter-day variations by UV-Spectroscopy are shown in Table 2 and Table 3, respectively.

Table 2: Intra-day variation studies data for Baricitinib

\begin{tabular}{|c|c|c|c|}
\hline \multirow{2}{*}{ Replicates } & \multicolumn{3}{|c|}{ Conc. $(\mu \mathrm{g} / \mathrm{ml})$} \\
\cline { 2 - 4 } & 20 & 30 & 50 \\
\hline & \multicolumn{3}{|c|}{ Absorbance } \\
\hline 1 & 0.715 & 1.024 & 1.628 \\
\hline 2 & 0.709 & 1.017 & 1.638 \\
\hline 3 & 0.708 & 1.002 & 1.649 \\
\hline Average & 101.710 & 100.455 & 0.674 \\
\hline SD & 0.643 & 1.235 & 0.674 \\
\hline \%RSD & 0.632 & 1.229 & \\
\hline
\end{tabular}


Table 3: Inter-day variation studies data for Baricitinib.

\begin{tabular}{|c|c|c|c|}
\hline \multirow{2}{*}{ Replicates } & \multicolumn{3}{|c|}{ Conc. $(\mu \mathrm{g} / \mathrm{ml})$} \\
\cline { 2 - 4 } & 20 & Absorbance & 50 \\
\hline & \multicolumn{3}{|c|}{} \\
\hline 1 & 0.711 & 1.049 & 1.627 \\
\hline 2 & 0.710 & 1.027 & 1.648 \\
\hline 3 & 0.709 & 1.011 & 1.659 \\
\hline Average & 101.590 & 102.008 & 1.056 \\
\hline SD & 0.113 & 2.045 & 1.046 \\
\hline \%RSD & 0.111 & 2.005 & \\
\hline
\end{tabular}

\section{Limit of Detection (LOD) and Limit of Quantification (LOQ):}

From the linearity data the LOD and LOQ as calculated, using the formula LOD $=3.3 \sigma / \mathrm{S}$ and $\mathrm{LOQ}=10 \sigma / \mathrm{S}$, where $\sigma=$ standard deviation of the $y$ intercept of linearity equations and $\mathrm{S}=$ slope of the calibration curve of the analyte. The LOD and LOQ by UV-Spectroscopy were found to be $0.250 \mu \mathrm{g} / \mathrm{ml}$ and $0.756 \mu \mathrm{g} / \mathrm{ml}$, respectively.

\section{Assay Procedure:}

In house drug formulation was prepared. Quantity of formulation equivalent to $10 \mathrm{mg}$ of drug was weighed and transferred to $10 \mathrm{ml}$ volumetric flask, dissolved in $1 \mathrm{ml}$ of DMSO and volume made to $10 \mathrm{ml}$ with methanol. The solution was filtered through Whatmann filter paper and it is suitably diluted with methanol to obtain the concentration of $10 \mu \mathrm{g} / \mathrm{ml}$. Procedure was repeated for six times. Results obtained are shown in Table 4.

Table 4: Assay of inhouse prepared formulation.

\begin{tabular}{|c|c|c|c|}
\hline SN & Absorbance & $\begin{array}{c}\text { Amount Recovered } \\
(\boldsymbol{\mu g} / \mathbf{m l})\end{array}$ & \% Recovery \\
\hline 1 & 0.390 & 10.003 & 100.026 \\
\hline 2 & 0.392 & 10.065 & 100.655 \\
\hline 3 & 0.390 & 10.002 & 100.019 \\
\hline 4 & 0.390 & 10.004 & 100.039 \\
\hline 5 & 0.390 & 10.005 & 100.055 \\
\hline 6 & 0.391 & 10.033 & 100.329 \\
\hline Mean & 0.391 & 10.019 & 100.187 \\
\hline SD & 0.001 & 0.026 & 0.258 \\
\hline \%RSD & 0.205 & 0.257 & 0.257 \\
\hline
\end{tabular}

\section{Accuracy:}

To check the accuracy of the method, recovery studies were carried out by addition of standard drug solution to pre- analyzed sample solution at three different levels $50 \%, 100$ $\%$ and $150 \%$. The drug concentrations and \% recovery was determined from linear equation. Results obtained are shown in Table 5.

Table 5: Accuracy of Baricitinib

\begin{tabular}{|c|c|c|c|c|c|}
\hline Level & $\begin{array}{c}\text { Conc. of Sample } \\
\text { solution } \\
(\mu \mathrm{g} / \mathrm{ml})\end{array}$ & $\begin{array}{c}\text { Conc. of Standard } \\
\text { solution spiked } \\
(\mu \mathrm{g} / \mathrm{ml})\end{array}$ & Absorbance & $\begin{array}{l}\text { Amount recovered } \\
(\mu \mathrm{g} / \mathrm{ml})\end{array}$ & $\begin{array}{c}\text { \% recovery } \pm \\
\% \text { RSD }\end{array}$ \\
\hline \multirow{3}{*}{$50 \%$} & \multirow{3}{*}{10} & \multirow{3}{*}{5} & 0.544 & 14.958 & \multirow{3}{*}{$\begin{array}{c}99.741 \pm \\
0.376\end{array}$} \\
\hline & & & 0.542 & 14.906 & \\
\hline & & & 0.546 & 15.019 & \\
\hline \multirow{3}{*}{$100 \%$} & \multirow{3}{*}{10} & \multirow{3}{*}{10} & 0.711 & 20.339 & \multirow{3}{*}{$\begin{array}{c}100.726 \pm \\
0.833\end{array}$} \\
\hline & & & 0.702 & 20.058 & \\
\hline & & & 0.701 & 20.039 & \\
\hline \multirow{3}{*}{$150 \%$} & \multirow{3}{*}{10} & \multirow{3}{*}{15} & 0.870 & 25.494 & \multirow{3}{*}{$\begin{array}{c}100.586 \pm \\
1.514\end{array}$} \\
\hline & & & 0.861 & 25.206 & \\
\hline & & & 0.877 & 24.739 & \\
\hline
\end{tabular}

\section{Robustness:}

Robustness of the method was determined by carrying out the analysis under conditions during which detection wavelength $( \pm 2 \mathrm{~nm})$ was altered and the effect on the absorbance was noted. The method was found to be robust. The result of the robustnesss for Baricitinib is shown in Table 6 
Tablet 6: Robustness Study for Baricitinib

\begin{tabular}{|c|c|c|}
\hline \multicolumn{3}{|c|}{ \% RSD Found For Robustness Study (Absorbance of $\mathbf{2 0} \boldsymbol{\mu g} / \mathbf{m l}$ ) } \\
\hline \multicolumn{3}{|c|}{ DETECTION WAVELENGTH ( $\mathbf{2 ~ \mathbf { ~ n m } )}$} \\
\hline $\mathbf{2 4 8}$ & $\mathbf{2 5 0}$ & $\mathbf{2 5 2}$ \\
\hline 0.636 & 0.648 & 0.635 \\
\hline
\end{tabular}

\section{RESULT AND DISCUSSION:}

In the proposed method, Baricitinib showed absorption maxima at $250 \mathrm{~nm}$. The calibration curve was found to be linear in the concentration range of $10-60 \mu \mathrm{g} / \mathrm{ml}$. Accuracy was determined by calculating the recovery. Precision was calculated as intra and inter day variation (\% RSD) for
Baricitinib. LOD value for Baricitinib was found to be 0.250 $\mu \mathrm{g} / \mathrm{ml}$ and LOQ value is and $0.756 \mu \mathrm{g} / \mathrm{ml}$ respectively. The method was successfully used to determine the amounts of Baricitiib present in formulation.

Table 7: Summary of Validation Parameters

\begin{tabular}{|c|c|c|}
\hline Sr. No. & Validation parameters & Baricitinib \\
\hline \multirow{3}{*}{1.} & Linearity equation & $\mathrm{y}=0.031 \mathrm{x}+0.080$ \\
& $\mathrm{R}^{2}$ & $\mathrm{R}^{2}=0.993$ \\
& Range & $10-60 \mu \mathrm{g} / \mathrm{ml}$ \\
\hline \multirow{3}{*}{2.} & Precision & $(\% \mathrm{RSD})$ \\
\cline { 2 - 3 } & Intraday & $0.632-1.229 \%$ \\
\hline 3. & Inter-day & $0.111-2.005 \%$ \\
\hline \multirow{3}{*}{4.} & Assay & $100.187 \%$ \\
\cline { 2 - 3 } & Accuracy & Mean $\pm \mathrm{RSD}$ \\
\cline { 2 - 3 } & $50 \%$ & $99.741 \pm 0.376$ \\
\hline 5. & $100 \%$ & $100.726 \pm 0.833$ \\
\hline 6. & $150 \%$ & $100.586 \pm 1.514$ \\
\hline 7. & Limit of detection & $0.250 \mu \mathrm{g} / \mathrm{ml}$ \\
\hline 8. & Limit of quantitation & $0.756 \mu \mathrm{g} / \mathrm{ml}$ \\
\hline
\end{tabular}

\section{CONCLUSION:}

The method proposed in the above study was found to be simple, specific, economic, precise and rapid for the determination of Baricitinib in bulk as well as in its dosage form. Being economic and precise, the developed method may conveniently adopted as an alternative method for the routine analysis of the Baricitinib in bulk and pharmaceutical dosage form.

\section{ACKNOWLEDGEMENT:}

The authors express their gratitude to $\mathrm{Dr}$ (Mrs) A. R. Madgulkar, Principal, A.I.S.S.M.S. College of Pharmacy, for providing necessary facilities and her constant support.

\section{REFERENCES:}

1. https://www.drugbank.ca/drugs/DB11817 ( Accessed on 4/9/18)

2. https://pubchem.ncbi.nlm.nih.gov/compound/Baricitinib (Accessed on 4/9/18)

3. https://en.wikipedia.org/wiki/Baricitinib (Accessed on 3/9/18)

4. Veeraraghavan S, Thappali SRS., Viswanadha S, Vakkalanka S Rangaswamy M, Simultaneous Quantification of Baricitinib and Methotrexate in Rat Plasma by LC-MS/MS: Application to a Pharmacokinetic Study, Journal of Scientia Pharmaceutica 2016; 84(2): 347-359

5. ICH guidelines for validation of analytical procedures: text and methodology Q2 (R1), Geneva, Switzerland, 2005, 1-17. 